\title{
結水河川における \\ 晶水粒径分布之晶水輸送量の現地観測 \\ FIELD OBSERVATION OF FRAZIL PARTICLE DISTRIBUTION AND FRAZIL TRANSPORT CAPACITY IN ICE-COVERED RIVERS
}

\author{
吉川泰弘 ${ }^{1}$ ・渡邊 康玄 ${ }^{2} \cdot$ 阿部 孝章 ${ }^{3}$ ・ 伊藤 丹 $^{4}$ \\ Yasuhiro YOSHIKAWA, Yasuharu WATANABE, Takaaki ABE, Akashi ITOU

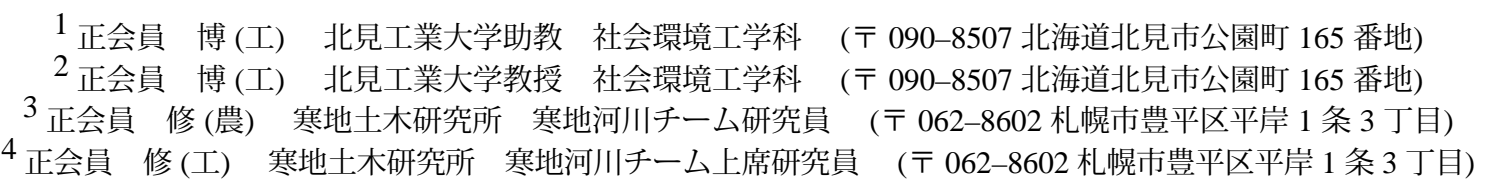

\begin{abstract}
Frazil particle distribution in ice-covered rivers is not well understood. In this paper, we carried out field observation in northern Hokkaido. In this result, shape of frazil particle distribution is sharper than normal distribution. and it is inclined to left side than normal distribution. Frazil particle size has two peaks, namely, high frequency size $(0.46 \mathrm{~mm})$ and average size $(2.45 \mathrm{~mm})$. Relationship between frazil transport capacity and dimensionless flow strength was investigated in an ice-covered river in Japan. Much frazil capacity has transported, because frazil particle size is small compared with previous research. Relationship between frazil particle size and 2nd power of shear velocity was examined. As the result, we considered transportation of frazil particle is smaller than transportation of soil particle.
\end{abstract}

Key Words: Ice covered River, Field Observation, Frazil particle distribution, Hokkaido

\section{1. はじめに}

冬期間における積雪寒冷地の河川は，気温の低下に 伴い河道内に河水が形成され結水する. 河水は硬い水 板と軟らかい晶水に大別される. 河水が流下する過程 で, 河水が河道内で堆積するとアイスジャムが発生す る. アイスジャムは, 河水が河道を閉塞させる現象で あり, 流下断面積を狭めるため, 急激な水位上昇を引 き起こす.アイスジャムは, Surface ice jam と Frazil ice jamの2つのタイプに区分される ${ }^{1)}$. Surface ice jam は, 結水初期および解水期に水面上において多量の河水が 堆積することにより発生する. Frazil ice jam は, 河川 結水時に水板下において多量の晶水が堆積することに より発生する。

日本においては, 解水期に Surface ice jam が発生し, 水位が約 $3 \mathrm{~m}$ まで急激に上昇した事例がある ${ }^{2)}$. Frazil ice jam においては, 水板下の晶水の堆積状況を明らか にした既往研究 ${ }^{3)}$ はあるが, 著者が知る限り北海道 1 級河川をみると, Frazil ice jam による水位上昇という 現象は確認できていない.一方, 晶水に関する問題全般 をみると, 河川内に建設された生活用水, 工業用水, 発 電用水等のための取水口に, 晶水および雪泥が流入し, 取水障害が引き起こされる問題がある.この問題に対 して様々な対策 4)-7) が検討されている. しかし, 晶水 がいつ発生しどのように輸送されるかについては, 十 分には解明されていない, 晶水の発生については, 現
地観測 ${ }^{8)}$ から, 最大で数 $\mathrm{mm}$ 程度の晶水が $10 \mathrm{~g} / \mathrm{m}^{2} / \mathrm{min}$ で発生していることを明らかにしている. 晶水の輸送 については, 現地観測, 水理実験, データ解析 ${ }^{1)}$ から, 輸送量を無次元せん断力で評価し, 輸送量は晶水の形 の影響を大きく受けることを指摘している．これらの 既往研究は有益な知見を得ているが, 晶水の大きさや 粒径分布に関しては, 観測手法が確立されていないた め, 十分には議論されていない.

本研究は, 晶水に関する工学的な諸問題を解決する ために，1つの手段となる数值計算モデルの開発を念 頭に抏き, この第一歩として, 晶水粒径分布と晶水輸 送量に関する知見を得ることを目的としている。本研 究では以下の内容を実施した。現地観測を実施し観測 データの解析を行った. 厳しい現場状況における晶水 粒径分布の測定方法を開発した. 得られた晶水粒径分 布を統計的に解析し, その特徵を明らかにした. 晶水 輸送量と無次元せん断力の関係が, 日本の河川におい ても成り立つか検討した. さらに, 晶水輸送時におけ る晶水粒径と摩擦速度の 2 乗の関係を検討した。

\section{2. 現地観測}

\section{(1) 観測日時と観測地点}

2010 年 12 月から 2011 年 3 月の期間において, 北海 道北部に位置する天塩川を対象に現地観測を実施した。 本観測の位置図を図-1 に示す。なお，本観測区間内は， 


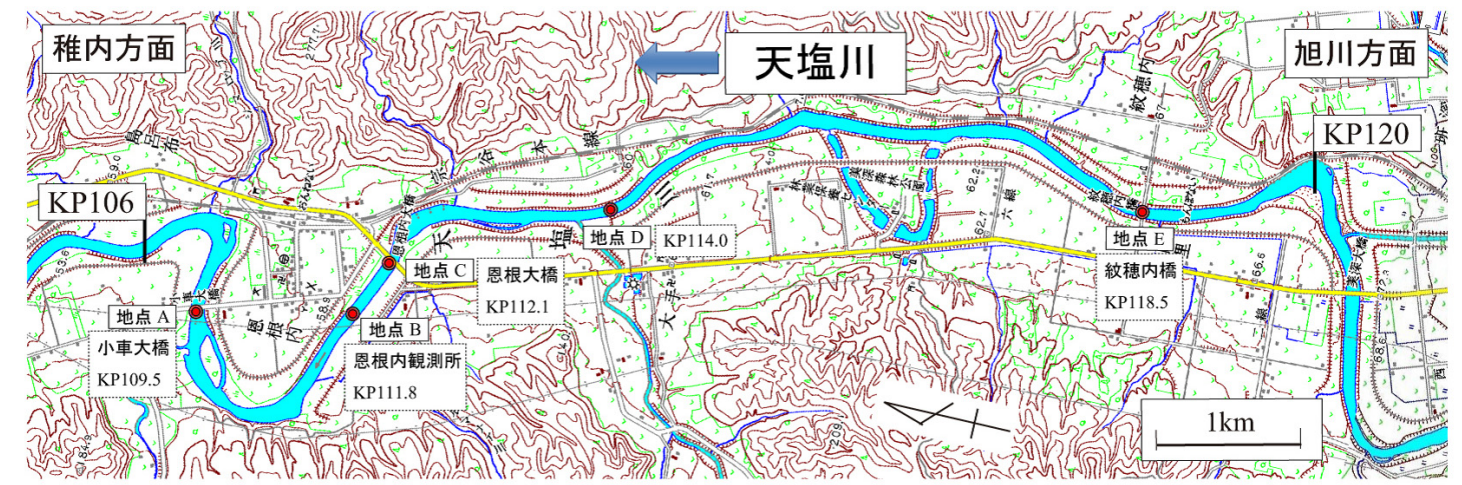

図-1 本観測の位置図 (KP はキロポストの略で河口からの距離 km，晶氷採取期間：Dec.20,2010 - Feb.20,2011)

2007 年 1 月から 2 月までの現地観測 ${ }^{8)}, 2008$ 年 1 月か ら 3 月までの現地観測 ${ }^{9)}$ から, 晶水が多く存在する区 間であることが分かっている.

\section{(2) 観測内容}

晶水採取は, 2010 年 12 月 20 日から 2011 年 2 月 20 日の期間において，図-1 の地点 $\mathrm{A} ， \mathrm{~B}, \mathrm{C}, \mathrm{D}, \mathrm{E}$ の 5 地点で計 189 回実施した. 地点 $\mathrm{B}$ においては, 晶水厚 の定期的な実測を計 5 回行った. 流速分布と晶水輸送 速度を測定 ${ }^{10)}$ するために, ADCP(WorkHorse Sentinel $1200 \mathrm{kHz}, \mathrm{RD}$ Instruments) を河床に設置し 10 分毎に連 続データを測定した。 晶水が存在しているか否かを判 断 3) するために, SWIP(Shallow Water Ice profiler ASL Environmental Sciences) を河床に設置した.これらの機 器は, 川幅約 $90 \mathrm{~m}$ の地点 B の横断面において, 右岸か ら $15 \mathrm{~m}$, 水深約 $2 \mathrm{~m}$ の位置に設置した. また, 結水状 況を把握するために，河口より $106 \mathrm{~km}$ 地点から $120 \mathrm{~km}$ 地点の区間において, 上空撮影を計 6 回行った.

上空撮影写真から平面結水比 ${ }^{11)}$ を算出した. 平面結 水比は值が大きいほど平面に占める結水の割合が大き くなり, 平面結水比が 1 で全面結水である. 平面結水比 は, 結水平面積 $\div$ 低水路平面積として求めた. 本検討で は, 結水平面積は低水路内における白色筒所を結水と 仮定して算出した. 区間毎の平面結水比の時間変化を 図-2 に示す．図-2 より，2010 年 12 月 28 日から 2011 年 1 月 26 日の期間において, KP110より上流は結水 が進み，KP110より下流は結水が進んでいない，既往 研究 ${ }^{12)}$ により算出した河床勾配において, KP106から KP110 の平均河床勾配は 1/753, KP110 から KP114 の 平均河床勾配は 1/1399 である. KP106 から KP110 は, 結水が進んでいる上流に比べて急勾配であるため, 流 速が速く結水が進まなかったと推定できる．本観測の 晶水採取地点は, 開水面がみえている部分結水, 水面 を河水が覆う完全結水という結水状況であったことが 分かる.

\section{(3) 晶水採取方法と晶氷粒径分布測定方法}

晶水採取について, 完全結水時は河水に空けた穴に バンドーン採水器を入れて採取し, 部分結水時は河水 上または橋上から紐付きバケツを開水面に入れて採取

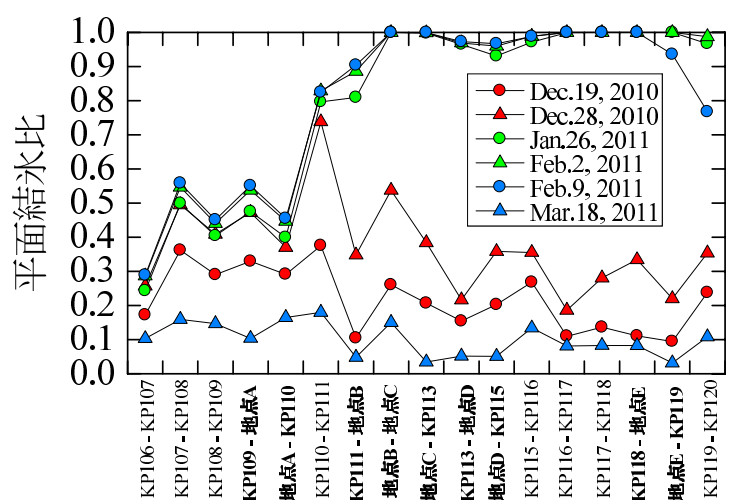

図-2 平面結水比の河川縦断変化 (天塩川 Dec.2010-Mar.2011)

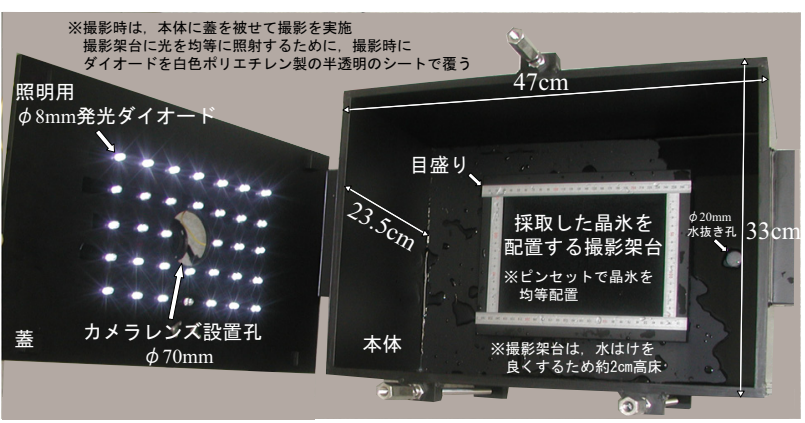

図-3 本観測で用いた晶氷粒径撮影装置

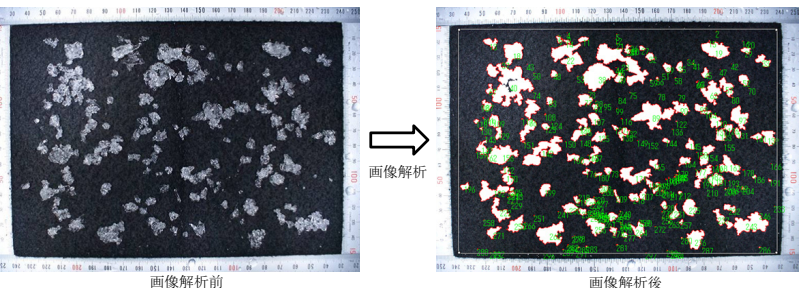

図-4 晶氷粒径の画像解析例 (地点 B，2011 年 2 月 14 日観測)

した. 採取した晶水を写真撮影した。 なお, 晶水採取時 に晶水が溶けて粒径が小さくなることを防止するため に, 晶水採取は気温低下時である朝方に実施した。 晶 水採取時には気温と水温を測定しており, 計 189 回の 平均気温は- $9.3^{\circ} \mathrm{C}$, 平均水温は $0.43{ }^{\circ} \mathrm{C}$ であり温度は低 い状況であった。 また, 晶水採取時および写真撮影時の 目視においても, 晶水が溶ける状況は確認されていな い. 写真撮影までの手順は, 採取した晶水を早急に目 の細かい水切り板に通して水切りを行い, 水切り板の 下にペーパータオルを当てて水分を吸い取らせる.こ の晶水を晶水粒径撮影装置の撮影架台に, 晶水同士が 重ならないようにピンセットを用いて配置し写真撮影 
を実施した。

晶水粒径撮影装置を図-3に示す．晶水は時間経過と ともに融解されるため, 採取後すぐに現場で撮影する 必要がある. 装置の製作に当たり, 雪, 雨, 風, 雲量に より現地状況が変化するなかで安定した撮影環境を作 るために, 雪, 雨, 風を防ぐ蓋を設置し, 一定の照度 となるように蓋に照明を設置した。

晶水粒径分布の測定方法は, 撮影した写真を, 画像解 析ソフト (Image-Pro Plus ver.4.0)を用いて, 各粒径の平 均直径, 最大直径, 最小直径および各粒径の個数を計測 した. 平均直径は粒子の重心を通る径を 2 度刻みに測定 した平均值, 最大直径は粒子の重心を通る最大の径, 最 小直径は粒子の重心を通る最小の径である. 図-4に画像 解析前後を示す. 画像解析ソフトの精度について, プラ ニメーター (Tamaya Digitizing Area Line Meter)による 実測值との比較を行った. $0.5 \mathrm{~mm}$ から $30 \mathrm{~mm}$ の 19 個の 粒子において最大直径と最小直径を比較した結果, 相関 係数は 0.95 以上であり測定精度は高いと判断した. なお, 画像解析に用いた画像の大きさは $3872 \times 2592$ pixel であ り, 画像解析における 1 pixel の実際の長さは $0.0867 \mathrm{~mm}$ である。

\section{3. 晶水粒径分布}

現地観測および画像解析により得られた計 189 回分 の晶水粒径において, 晶水粒径を平均直径とした場合 の晶水粒径分布を対象に, 度数分布と加積曲線の特徵, 晶水粒径の算術平均值と最頻值について検討を行った.

\section{(1) 度数分布と加積曲線}

度数分布の特徴をみる指標として歪度 (わいど) と尖 度 (せんど) がある. 歪度は, 度数分布が対称か非対称 かをみるものである. 左右対称である正規分布を基準 に, 分布が左側に広がっている場合の歪度は正の值で あり, 分布が右側に広がっている場合の歪度は負の值 とある. 歪度がゼ口の場合は正規分布となる. 尖度は, 度数分布が尖っているかをみるものである. 正規分布 の場合は尖度が 3 である. 分布が尖っている鋭峰の場 合の尖度は 3 以上の值であり, 分布が尖っていない鈍 峰の場合の尖度は 3 以下の值となる. 歪度は偏差 3 乗 平均 3 乗根の法を用い, 尖度は偏差 4 乗平均 4 乗根の 法を用いた ${ }^{13)}$. 晶水粒径分布の歪度と尖度を図-5 に示 す. 歪度は正の值であり尖度は 3 以上である. 晶水粒 径分布は, 正規分布に比べて左側に分布しており尖っ ている度数分布の特徴があると分かる.

土の粒度試験で用いられている粒径加積曲線におけ る均等係数と曲率係数について, 本観測で得られた晶 水の粒径加積曲線へ適用した. 均等係数は粒径加積曲 線の傾きを表したもので, 曲率係数は粒径加積曲線のな だらかさを表したものである．粒度分布が良い場合は, 均等係数が 10 以上, 曲率係数が 1 以上で $(\text { 均等係数 })^{1 / 2}$ 以下の場合 ${ }^{14)}$ である. 均等係数と曲率係数を図-6に示

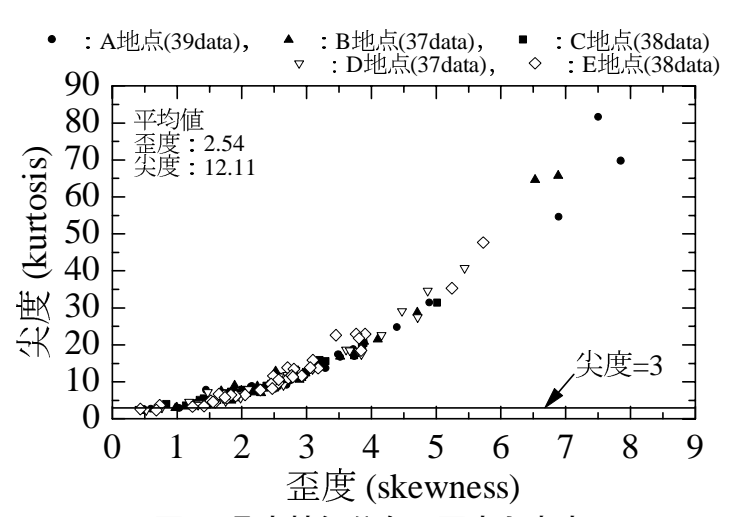

図-5 晶水粒径分布の歪度と尖度

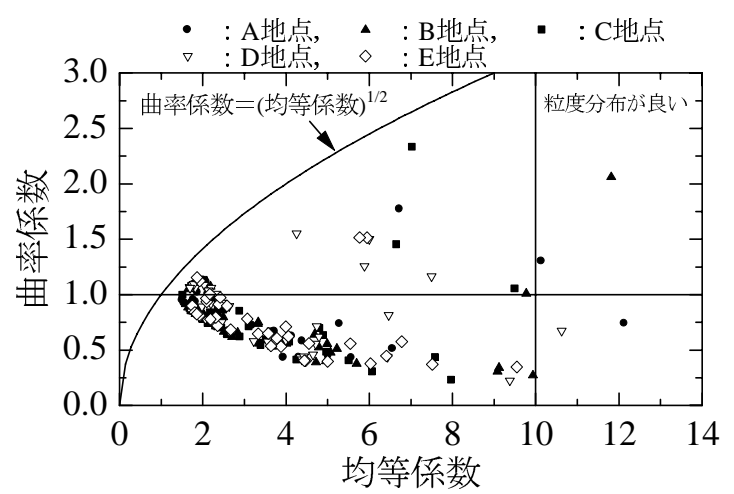

図-6 晶水粒径加積曲線の均等係数と曲率係数

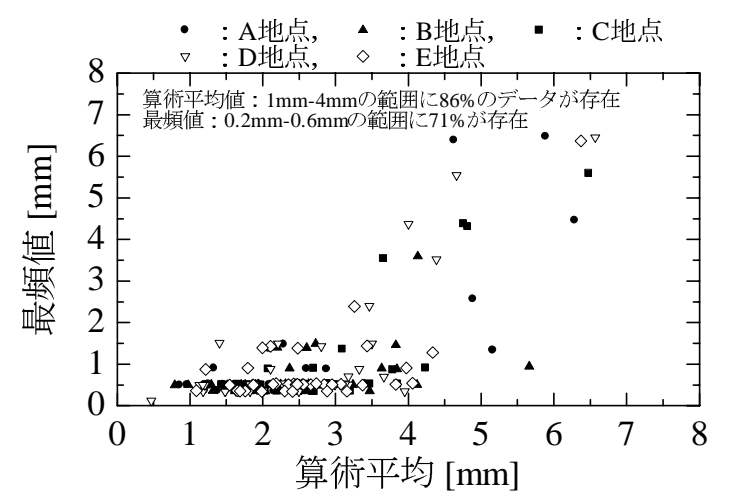

図-7 晶水粒径の算術平均と最頻値

す. 図-6 より, 晶水粒径分布を土の粒度試験に適用す ると「粒度分布が悪い」と言える。

\section{(2) 算術平均値と最頻値}

本観測で得られた晶水粒径分布は, 正規分布に比べ て左側に偏っており尖っていることが明らかとなった. 左右非対称の度数分布の場合, 一般に用いられる全デー 夕の和を個数で割った算術平均值と最も多い頻度で出 現する最頻値は乘離する. その程度を明らかにするため に, 晶水粒径分布の算術平均值と最頻值を図-7 に示す. 図-7 より算術平均值と最頻值は乘離してることが分か る. 算術平均值は, $1 \mathrm{~mm}$ から $4 \mathrm{~mm}$ の範囲に全データ の $86 \%$ が収まり,この範囲の平均值は $2.45 \mathrm{~mm}$ である. 最頻值は, $0.4 \mathrm{~mm}-0.6 \mathrm{~mm}$ の範囲に全データの $71 \%$ が収 まり，この範囲の平均值は $0.46 \mathrm{~mm}$ である.

計 189 回の晶水粒径分布における晶水粒径の度数分 布と加積曲線の平均值を図-8に示す. 図-8 の粒径が小 さい方からみていくと， $0.2 \mathrm{~mm}$ から $1.0 \mathrm{~mm}$ の晶水で 


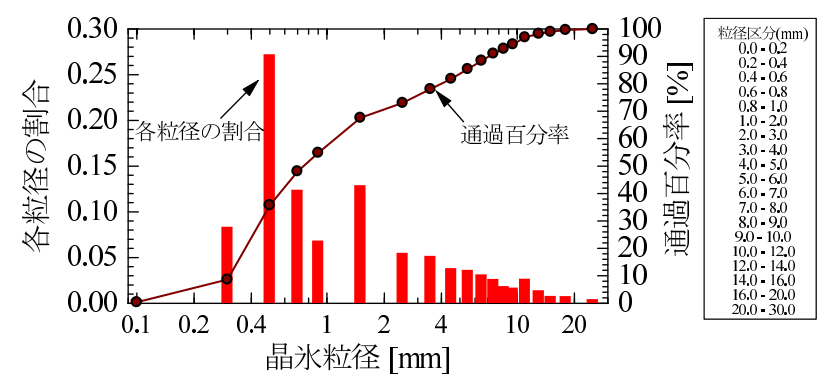

図-8 晶永粒径の度数分布と加積曲線

は, $0.4 \mathrm{~mm}-0.6 \mathrm{~mm}$ の晶水が多く存在し， $0.2 \mathrm{~mm}-0.4 \mathrm{~mm}$ の晶水と $0.6 \mathrm{~mm}-1.0 \mathrm{~mm}$ の晶水は少ない. $1.0 \mathrm{~mm}$ 以上の 晶水では, $1.0 \mathrm{~mm}-2.0 \mathrm{~mm}$ の晶水が多く存在し, その後 は粒径の大きさに比例して少なくなる. 現地観測から, $0.4 \mathrm{~mm}-0.6 \mathrm{~mm}$ の晶水と $1.0 \mathrm{~mm}-2.0 \mathrm{~mm}$ の晶水は, 前後 の晶水粒径と比較して多く存在することが分かり, 晶 水粒径分布は晶水粒径 $1 \mathrm{~mm}$ を境に 2 つのピークを持つ ことが示唆された. また， $0.4 \mathrm{~mm}-0.6 \mathrm{~mm}$ の晶水は最頻 值の区分と同じであり, $1.0 \mathrm{~mm}-2.0 \mathrm{~mm}$ の晶水は算術平 均值に近い区分であった。

\section{4. 晶水輸送量}

本研究で得られた観測データを用いて, 晶水輸送量 と無次元せん断力の関係および晶水輸送時における晶 水粒径と摩擦速度の 2 乗の関係について検討を行った.

\section{（1）晶水輸送量と無次元せん断力}

晶水の形の影響を考慮した晶水輸送量と無次元せん 断力は, $\mathrm{Shen}^{1)}$ により提案された式(1)と式 (2)で表わ される。

$$
\begin{gathered}
\Phi=\frac{q_{f}}{F \sqrt{\Delta g d_{f}^{3}}} \\
\Theta=\frac{U_{*}^{2}}{F^{2} \Delta g d_{f}}
\end{gathered}
$$

ここで, $\Phi$ : 無次元晶水輸送量, $\Theta$ : 無次元せん断力, $q_{f}\left[\mathrm{~m}^{2} / \mathrm{s}\right]$ : 単位幅晶水輸送量 (=晶水厚 $h_{f} \times$ 晶水速度 $\left.u_{f}\right)$, $d_{f}[\mathrm{~m}]$ : 晶水粒径, $U_{*}[\mathrm{~m} / \mathrm{s}]$ : 摩擦速度, $F$ [無次元 $]$ : 沈 降速度係数, $\Delta$ [無次元 $]$ : 水中比重で $\left(\rho_{w}-\rho_{i}\right) / \rho_{w}$ となり, $\rho_{w}\left[\mathrm{~kg} / \mathrm{m}^{2}\right]$ : 水の密度で 1000 を与え, $\rho_{i}\left[\mathrm{~kg} / \mathrm{m}^{2}\right]$ : 水の密 度で 917 を与えた. $g\left[\mathrm{~m} / \mathrm{s}^{2}\right]$ : 重力加速度で 9.8 を与え た. なお, Rubey ${ }^{15)}$ により提案された沈降速度係数 $F$ は, 沈降速度 $\omega[\mathrm{m} / \mathrm{s}]$ と式 (3) の関係にある.

$$
\omega=F \sqrt{\Delta g d_{f}}
$$

晶水厚 $h_{f}$ は, 観測值を用いて線形補完を行い連続 的に值を得た. 晶水速度 $u_{f}$ は, 既往研究 ${ }^{10)}$ を参考に, ADCP のトラッキング值を用いた. 動いている河水が 水板か晶水かについては, SWIPの実測值から晶水であ ることを確認している.

晶水粒径 $d_{f}$ について, 本研究の晶水粒径分布の解析

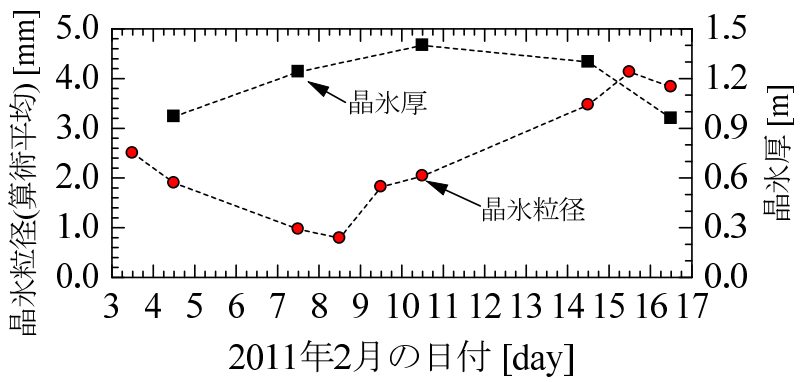

図-9 晶永粒径と晶永厚の観測値 (地点 $\mathbf{B}$ )

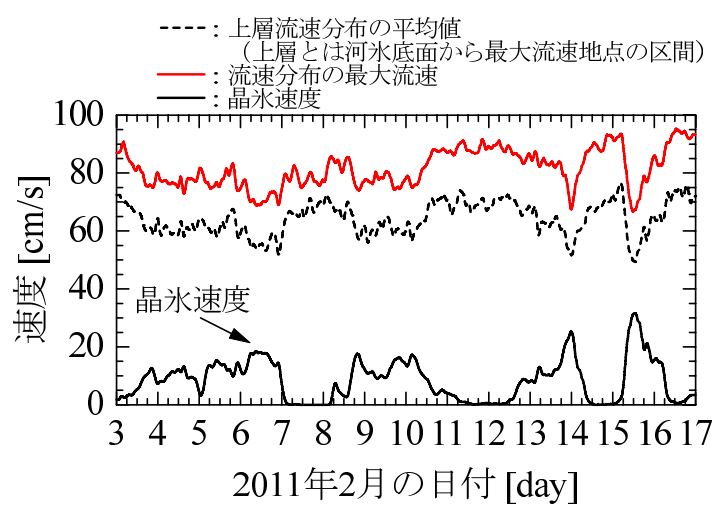

図-10 ADCP から得られた流速と晶水速度の測定値 (地点 B)

から, 算術平均值と最頻值で值が異なることが分かっ た. 晶水粒径 $d_{f}$ を算術平均值とするか最頻值とするか は議論が必要である. 本研究では以下の仮説を立てて 検討を進めた. 晶水粒径分布において 2 つのピークが あったことから, 小さい粒子は浮遊砂的な挙動を示し, 大きな粒子は掃流砂的な挙動を示すと仮定した. 式 (1) と式 (2) は, 土砂の掃流砂量式の考えに基づいて導かれ ていることから, 晶水の掃流砂的な挙動を対象として いると考えられる. このため, 本研究では, 晶水粒径 は 2 つのピークの内, 大きい粒子である算術平均值と した.

摩擦速度 $U_{*}$ は, ADCP の流速分布から推定した. 河 川結水時の流速分布は, Ashton ${ }^{16)}$ にならい式 (4) とし た. 最大流速 $u_{\max }$ とその地点から河水底面までの距離 $y_{\text {max }}$ を式 (4) に代入し, 相当粗度高 $k_{s}$ を表わすと式 (5) となる. 式 (5) を式 (4) に代入すると式 (6) が導かれる. 図-11に, 結水河川の流速分布の観測值と式 (4) の計算 值の一例を示す. 図より, 式 (4) は観測した流速分布を 良く再現していることが分かる.

$$
\begin{gathered}
u=2.5 U_{*} \ln \left(\frac{30 y}{k_{s}}\right) \\
k_{s}=\exp \left(\ln \left(30 y_{\max }\right)-\frac{u_{\max }}{2.5 U_{*}}\right) \\
U_{*}=\frac{u-u_{\max }}{2.5 \ln \left(\frac{y}{y_{\max }}\right)}
\end{gathered}
$$

ADCP から得られた平均流速 $\bar{u}$ とその地点の水深 $\bar{y}$ を, 式 (6)の $u$ と $y$ に代入すれば $U_{*}$ が算出できる. ここで, 平均流速 $\bar{u}$ は最大流速 $u_{\max }$ とその地点から河水底面ま での距離における值であり，水深 $\bar{y}$ は簡便のため $y_{\max }$ の中心と仮定して $\bar{y}=y_{\text {max }} / 2$ とした. 図-11 の観測值 


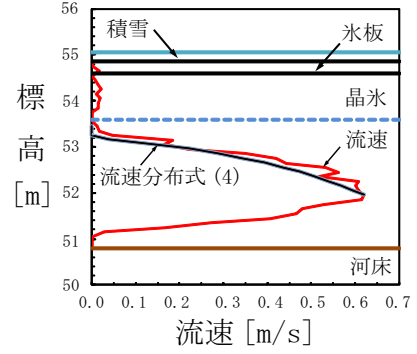

図-11 結水河川の流速分布の一例 (2011 年 1 月 14 日，恩根 内観測所 (地点 $\mathrm{B}$ ), 左岸から $65 \mathrm{~m}$ 地点, 電磁流速計で 水深 $10 \mathrm{~cm}$ 毎に測定)

において，実測した $\bar{y}$ と $y_{\text {max }} / 2$ の䛊差は $y_{\text {max }}$ に対して 8\%であった. 本検討では簡便であり䛊差が小さいこと から $\bar{y}=y_{\max } / 2$ と仮定して検討を進めた.

晶水厚 $h_{f}$, 晶水粒径 $d_{f}$, 晶水速度 $u_{f}$, 平均流速 $\bar{u}$, 最大流速 $u_{\max }$ を図-9,10 に示す. 沈降速度係数 $F$ は, Mantz ${ }^{17)}$ の式 (7) で表わされる.

$$
\begin{gathered}
\frac{1}{F}=3.18-18.22 \alpha_{p}+80.46 \alpha_{p}^{2} \\
-171.46 \alpha_{p}^{3}+140.95 \alpha_{p}^{4} \\
\alpha_{p}=\frac{c}{\sqrt{a b}}
\end{gathered}
$$

$a[\mathrm{~m}]$ : 長径, $b[\mathrm{~m}]$ : 中間の径で算術平均を与えた. $c[\mathrm{~m}]$ : 短径である.ここで変数を減らすために, 式(9) と式(10) を仮定した。

$$
\begin{aligned}
& a=A \times c \\
& b=\frac{a+c}{2}
\end{aligned}
$$

A は定数である. 式 (9) の関係について, 画像解析から 得られた值を図-12 に示す．図-12より相関が高いこと が分かり，式 (9) は成立することが推定される. 図-12 において定数 A は約 2 であり, 晶水の長径は短径の約 2 倍であることを示している.

式 (10) の関係について, 画像解析から得られた值を 用いて, 中間の径 $b$ と $(a+c) / 2$ の相関係数を求めた. 相関係数は 0.9997 と相関が高く, 画像解析から得られ た值において式 (10) は成立することが分かる.

また，式(9) と式 (10)を連立させると式 (11) となり, 中間の径 $b$ をちれば, 式 (7), 式 (8), 式 (9)を用いて 沈降速度係数 $F$ を算出することが可能となる.

$$
c=\frac{2 b}{1+A}
$$

上記の手法で得た観測值を式 (1) と式 (2) に代入し, 得た值を図-13 に示す. 図-13 には, Shen の論文 ${ }^{1)} に$ 記載されている既往研究の值および実測值と一致する 関係式を示している. 図-13より本観測データはばらつ きが大きい. この要因として, 与えた晶水粒径 $d_{f}$ およ び晶水厚 $h_{f}$ は, 観測值データを線形補完して与えてい るため, 摩擦速度 $u_{*}$ や晶水速度 $u_{f}$ のような連続デー

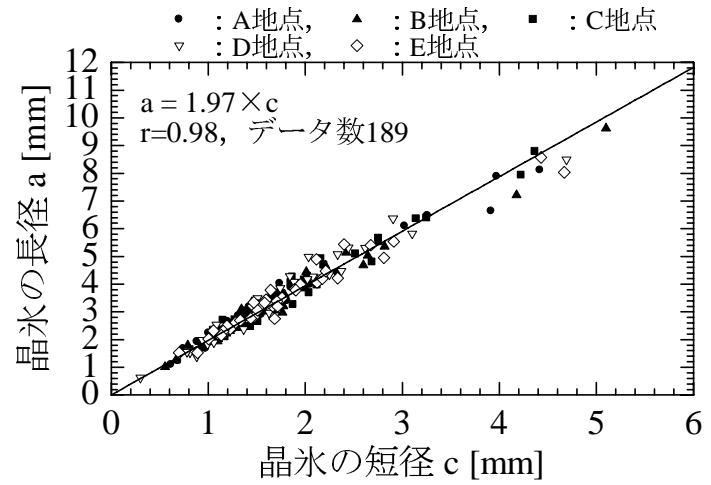

図-12 晶氷粒径における短径と長径

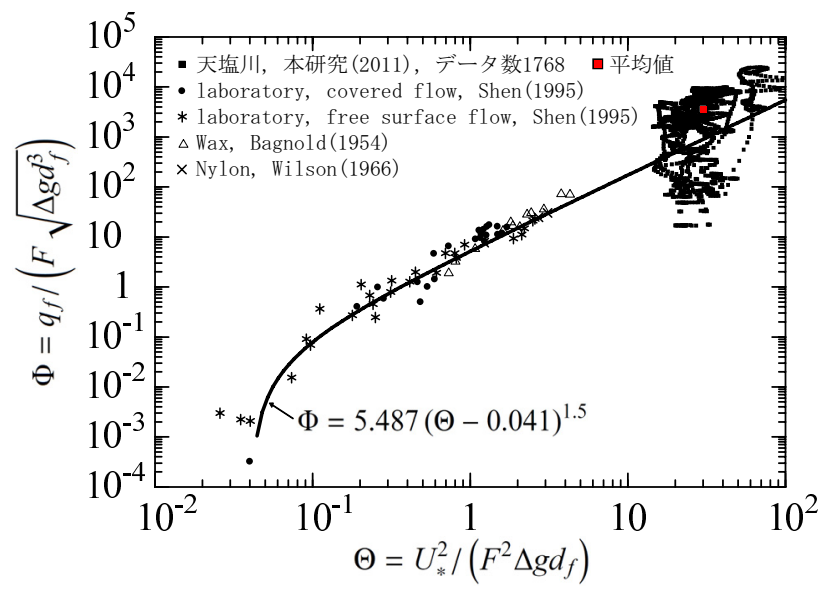

図-13 晶氷における無次元せん断力と単位幅輸送量

タとなっていない. このため晶水粒径 $d_{f}$ および晶水厚 $h_{f}$ の時系列変化を適切に与えていないため, ばらつき が大きくなったと推察できる. 一方で, 晶水粒径 $d_{f}$ お よび晶水厚 $h_{f}$ は, 時々刻々と変化していることを示唆 している. 図-13より, 本観測データは, 実測值と一致 する関係式の近傍にあり, 值は既往研究の值に比べて 大きい. 仮に晶水粒径を 10 倍にして計算したところ, 実測值と一致する関係式の線上に沿って， $\Phi$ および $\Theta$ の值が小さくなった. 值が大きい要因として晶水粒径 が小さいことが上げられる。このことは, 本観測地点 は, 晶水粒径が既往研究に比べて小さいため, より多 くの晶水が輸送されることを示している.

\section{(2) 晶水粒径と摩擦速度の 2 乗}

河床に存在する土粒子が掃流力により移動するか否 かを判断する際には, 粒径と摩擦速度の 2 乗の関係式 を用いる方法がある. 本検討は, 土粒子の移動判定の考 えに基づき, 晶氷輸送時の晶水粒径と摩擦速度の 2 乗 の関係を検討した. 本観測データを用いて, 晶水粒径 と摩擦速度の 2 乗の関係を図-14 に示す。図-14より, 本観測データは上下に振幅をもっている，要因として， 本河川の上流に発電施設を持つダムが存在し, 発電の ために放流を繰り返しているためと推定できる。

図-14には, 晶水の輸送がある場合とない場合の值を 示している. また, 晶水の輸送がある場合の観測デー タを用いて, 最小二乗法により求めたべき関数を示し, 一様粒径砂礫の限界掃流力の算定式である岩垣の式 18) 


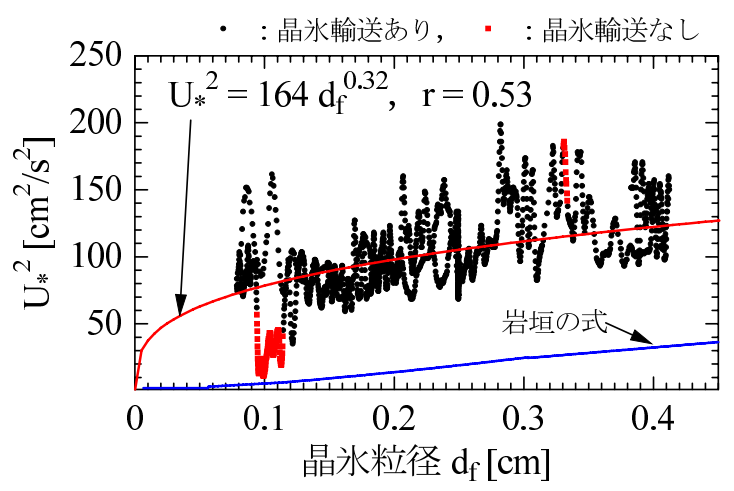

図-14 晶氷粒径と摩擦速度の 2 乗

を示した. 図中の岩垣の式より上の值であれば土粒子 は移動することになる.

図-14 の晶水粒径約 $0.1 \mathrm{~mm}$ 付近と晶水粒径約 $0.33 \mathrm{~mm}$ 付近において, 晶水が輸送されていない期間がある.こ の期間は図-10における晶水流速がゼロとなる期間で あり, SWIPのデータをみると晶水濃度が薄いため晶水 自体が存在していない可能性がある. 晶水を輸送する 流体力はあるものの, この地点に晶水が存在していな い状況と考えられる.

図-14より，本観測データは全て岩垣の式よりも上に 位置し，土粒子であれば移動する条件となっている．岩 垣の式と観測データから求めたべき関数との間に乘離 があることから，本観測データだけでは結論付けられ ないが, 晶水は土粒子に比べて輸送されにくいことが 予見される.

\section{5. おわりに}

本研究は, 従来まで明らかとされていなかった晶水 の粒径分布について, 厳しい現地状況に対応した晶水 粒径撮影装置を開発し, 得られた晶水粒径分布の解析 から以下のことが分かった. 晶水粒径分布は，正規分 布に比べて左側に分布しており尖っている度数分布の 特徵がある. 晶水粒径分布は, 晶水粒径 $1 \mathrm{~mm}$ を境に $0.4 \mathrm{~mm}-0.6 \mathrm{~mm}$ の晶水と $1.0 \mathrm{~mm}-2.0 \mathrm{~mm}$ の晶水の 2 つの ピークを持つことが示唆された．また， $0.4 \mathrm{~mm}-0.6 \mathrm{~mm}$ の晶水は最頻值の区分と同じであり, $1.0 \mathrm{~mm}-2.0 \mathrm{~mm}$ の 晶水は算術平均值に近い区分であることが分かった.

日本の結水河川においても晶水輸送量と無次元せん 断力の関係が見い出された。本観測地点は, 晶水粒径 が海外の既往研究に比べて小さいため, より多くの晶 水が輸送されていることが推察された。晶水粒径が小 さい要因として, 気温, 水温, 流速等が考えられる. こ れらの要因が, 晶水粒径にどの程度影響を評与えてい るかを評価するためには，観測データを蓄積し検討を 重ねる必要がある.

晶水輸送時における晶水粒径と摩擦速度の 2 乗の関 係を検討し, 晶水は土粒子に比べて輸送されにくいこ とが予見された.

謝辞：Clarkson University の Professor Hung Tao Shen に は本研究の着想を頂いた。北海道開発局より資料提供
の御協力を頂いた，福田水文センター，北海道フィー ルドサポートより現地観測等の御協力を頂いた。本研 究は科研費基盤研究 (B)24360197 および河川整備基金 24-1114-001 の助成を受けたものである．記して謝意を 表します。

\section{参考文献}

1) Shen, H. T., and Wang, D. S. : UNDER COVER TRANSPORT AND ACCUMULATION OF FRAZIL GRANULES, Journal of Hydraulic Engineering, Vol.121, No.2, February, pp184-195, 1995.

2) 吉川泰弘, 渡邊康玄, 早川博, 平井康幸 : 2010 年 2 月 に渚滑川で発生したアイスジャムに関する研究, 土木学 会，河川技術論文集,第 17 巻, pp.353-358, 2011.

3) 橋場雅弘, 吉川泰弘, 渡邊康玄：結水河川における SWIP を用いた河水の晶水厚の測定, 土木学会, 河川技術論文 集, 第 16 巻, pp.271-276, 2010.

4) 峯田稔, 山崎誠, 平山健一, 杉田誠：小規模寒地河川に おける流水雪制御方法に関する研究, 水工学論文集, 第 37 巻, pp.135-140, 1993.

5) 植田知行, 高橋喜一, 羽山芳則, 宇佐見宣拓, 佐伯浩 : 寒地技術シンポジウム, 第 19 回, pp.356-363, 2003.

6) 植田知行, 原文宏, 高橋喜一, 羽山芳則, 宇佐見宣拓, 佐伯浩：寒地技術シンポジウム，第 19 回, pp.364-370, 2003.

7) Daly, S. F.:Frazil Ice Blockage of Intake Trash Racks, CRREL, Cold Regions Technical Digest, No.91-1, pp.1-12, 1991.

8) 宇佐美宣拓, 吉田剛, 山下俊彦: 寒冷地河川で発生する 晶水に関する現地観測, 水工学論文集, 第 52 巻, pp.499504, 2008 .

9) 吉川泰弘, 渡邊康玄, 早川博, 清治真人 : 水板下におけ る晶水厚の連続測定, 土木学会, 水工学論文集, 第 53 巻, pp.1027-1032, 2009.

10）橋場雅弘, 吉川泰弘：天塩川における河川解水時の河水 の挙動に関する現地観測, 土木学会, 河川技術論文集, 第 17 巻, pp.365-370, 2011.

11）吉川泰弘, 渡邊康玄, 早川博, 平井康幸 : 河川解水時の 河水の破壊と流下に関する研究，土木学会論文集 B1（水 工学), Vol.67, No.4, pp.I_1075-I_1080, 2011.

12) 吉川泰弘, 渡邊康玄, 早川博, 平井康幸 : 寒地河川にお ける河水変動と水位変化に関する研究, 土木学会, 河川 技術論文集, 第 16 巻, pp.247-252，2010.

13) 岸根卓郎: 理論・応用 統計学, 株式会社養賢会, 訂正第 2 版, pp.68-74, 1968.

14）河上房義: 土質力学, 森北出版株式会社, 第 6 版, pp. 15 , 1997.

15) Rubey, W. W. : Settling velocities of gravel, sand, and silt particles, American Journal of Science, 25(148), pp.325338, 1933.

16) Ashton, G. D. : RIVER LAKE ICE ENGINEERING, Water Resources Publications, LLC, second printing, pp.308, 2004.

17) Mantz, P. A. : Low sediment transport rates over flat beds, Journal of Hydraulic Div.,ASCE, 106(7), pp1173-1190, 1980.

18）椿東一郎：水理学 (第 14 章), 基礎土木工学全書 7(森 北出版), 1974.

(2012.9.30 受付) 